\title{
Isolated coccygeal tuberculosis
}

\section{B M I K Thilakarathne', R N Waduge ${ }^{1}$, R Kotakadeniya², D Madegedara ${ }^{3}$}

Ceylon Medical Journal 2015; 60: 67-8

Tuberculosis is a chronic infection caused by Mycobacterium tuberculosis. While extrapulmonary tuberculosis can involve many organs in the body, isolated coccygeal tuberculosis is rare.

A 47-year old female presented with a purulent discharge per anum for 14 months. During examination under anaesthesia a 'sinus' was found extending from six o'clock position at dentate line into the post-anal space. The primary opening was at the upper end of a fissure-in-ano (Figure 1). She underwent exploration of the post-anal space where a partially destroyed coccyx was found in an 'abscess cavity'. The granulation tissues and parts of coccyx were sent for histopathology. The biopsy specimen consisted of multiple pieces of bone admixed with friable soft tissue, measuring 1 $\square 1 \square 0.2 \mathrm{~cm}$. Microscopy showed multiple well formed epithelioid granulomata with caseous necrosis surrounded by Langhan's type multinucleated giant cells characteristic of typical tubercluous-granulomata (Figure 2). Stains for fungi excluded a possible fungal infection. Acid fast stains were inconclusive [1]. Because of the typical caseating epithelioid granulomata within the necrotic bony trabacules, a diagnosis of "tuberculous osteomyelitis of coccyx" was made. The chest radiograph did not show any evidence of past or present pulmonary tuberculosis.

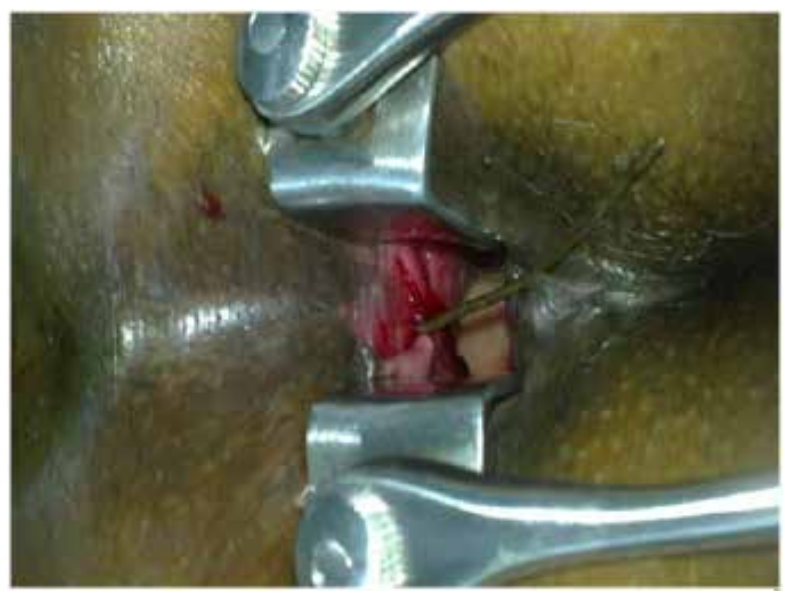

Figure 1. At examination under anesthesia, showing the sinus tract - the probe is passed from the primary opening to the tract.
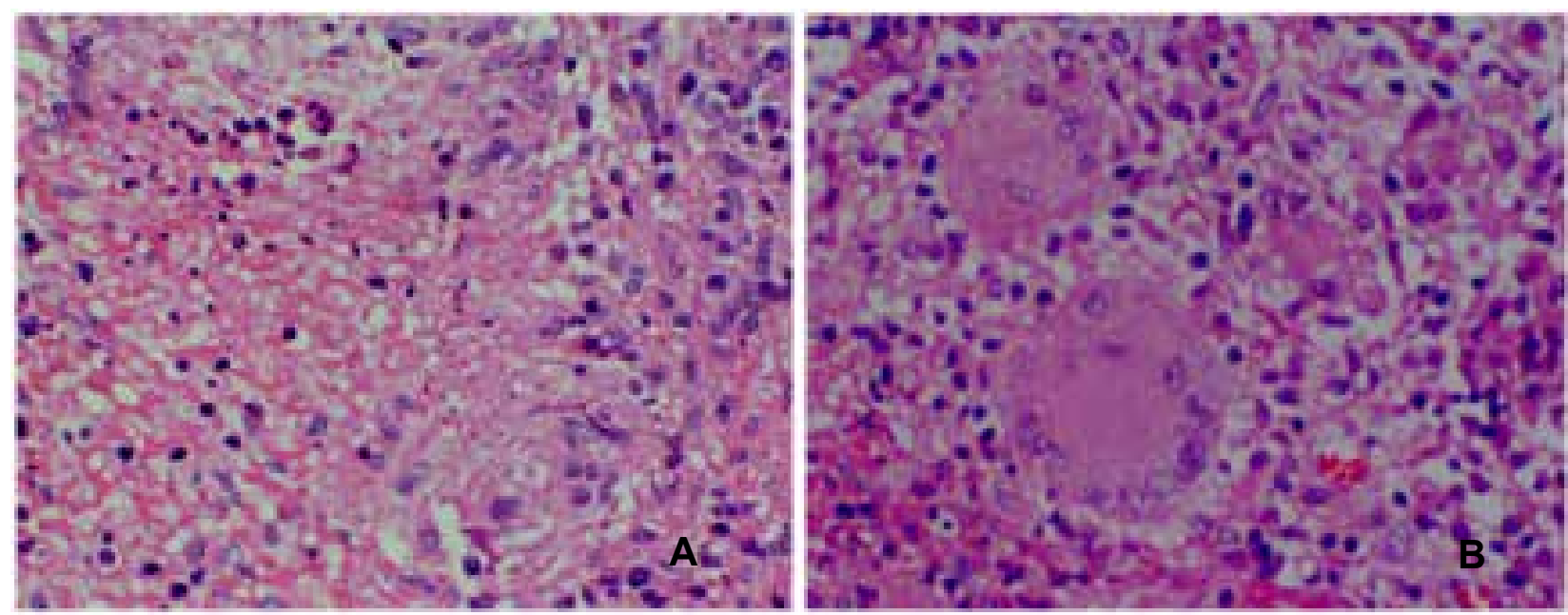

Figure 2. Photomicrograph of the lesion (Hematoxylin and Eosin $x 400$ ) showing caseating necrosis (A) and Langhan type giant cells (B).

Departments of ${ }^{1}$ Pathology and ${ }^{2}$ Surgery, Faculty of Medicine, University of Peradeniya and ${ }^{3}$ Teaching Hospital, Kandy, Sri Lanka.

Correspondence: BMIKT, e-mail: <ireshakvithanage@yahoo.com>. Received 23 October 2014 and revised version accepted 6 February 2015. 
The sputum culture was negative. Post operatively she was treated with anti-tuberculous medications. The wound completely healed after 10 months.

Tuberculosis (TB) remains a major global health problem. Isolated sacral tuberculosis usually presents as chronic back pain in adults and discharging sinuses or abscess formation in children, with or without neurological deficit [2].

Definitive diagnosis of tuberculosis involves demonstration of Mycobacterium tuberculosis by microbiological, cytopathological or histopathological methods. Histological examination of the biopsy usually shows epithelioid granulomas, Langhans' type multinucleated giant cells and caseous necrosis, as in this patient's biopsy specimen [3]. Demonstration of acid fast bacilli by special stains is also possible. Only $35-60 \%$ of cases can be diagnosed by demonstrating acid-fast bacilli in the biopsy specimen. Culture of the biopsy material may increase the diagnostic yield [2]. Other tests include polymerase chain reaction (PCR) to detect mycobacterial DNA and enzyme-linked immunosorbent assays (ELISAs) [4].

\section{Conflicts of interest}

We declare that there are no conflicts of interest.

\section{References}

1. Kumar A, Varshney MK, Trikha V, Khan SA. Isolated tuberculosis of the coccyx. J Bone Joint Surg Br 2006; 88: 1388-9.

2. KimDoUn, Kim SW, Ju CL. Isolated coccygeal tuberculosis. J Korean Neurosurg Soc 2012; 52: 495-7.

3. Kumar V, Abbas A, Fausto N, Aster J. Robbins and Cotran Pathologic Basis of Disease: Chronic inflammation. $8^{\text {th }}$ edition. China: Saunders Elsevier 2010.

4. Barker JA, Conway AM, Hill J. Supralevator fistula-in-ano in tuberculosis. Colorectal Dis 2011; 13: 210-4. 